\title{
AS RELAÇÕES DIALÓGICO-VALORATIVAS NO GÊNERO CARTA DE CONSELHOS EM REVISTAS ONLINE ${ }^{1}$
}

\author{
THE DIALOGIC AND VALORATIVE RELATIONSHIPS IN ADVICE LETTER \\ DISCOURSE GENRE ON ONLINE MAGAZINES
}

\author{
Rodrigo Acosta Pereira \\ Docente da Universidade Federal do Rio Grande do Norte \\ drigo_acosta@yahoo.com.br
}

\begin{abstract}
RESUMO: Diferentes pesquisas em Linguística Aplicada têm buscado compreender a constituição e o funcionamento dos gêneros do discurso nas mais variadas esferas da atividade humana. Sob essa perspectiva, procuramos apresentar uma análise das relações dialógicas e dos tons avaliativos que se engendram no funcionamento do gênero carta de conselhos publicado em revistas online. Para tanto, baseados nos pressupostos teórico-metodológicos dos escritos do Círculo de Bakhtin e em pesquisas contemporâneas sob o escopo da Análise Dialógica do Discurso, selecionamos 30 exemplares do gênero carta de conselhos em circulação nas revistas Claudia, Nova e Veja, versões online. Acreditamos que nossa pesquisa apresenta-se relevante, à medida que não apenas contribui para a consolidação de estudos na área dos gêneros do discurso, como, por conseguinte, colabora para o desenvolvimento de pesquisas de matiz bakhtiniano no campo da Linguística Aplicada.
\end{abstract}

PALAVRAS-CHAVES: Cartas de conselhos; Relações dialógicas; Valoração.

ABSTRACT: Several researches in Applied Linguistics have been searching for comprehending the constitution and the functioning of the discourse genres in the different human activity spheres. In this perspective, we seek for presenting an analysis of the dialogic relationships that are constituted in the advice letter genre functioning published on online magazines. To do so, we based our study on written works from Bakhtin's Circle and contemporary investigations in Dialogic Discourse Analysis as well as we selected 30 (thirty) texts from advice letter genre published on magazines on the internet: Claudia, Nova and Veja. We believe our research is relevant not only because it contributes to the consolidation of discourse genre studies, but also because it collaborates to the development of bakhtinian studies in Applied Linguistic area.

KEYWORDS: Advice letters; Dialogic relationships; Evaluation.

\footnotetext{
${ }^{1} \mathrm{O}$ presente artigo baseia-se nos resultados da pesquisa de doutorado, O gênero carta de conselhos em revistas online: na fronteira entre o entretenimento e a autoajuda (ACOSTA-PEREIRA, 2012), orientada pela Profa. Dra. Rosângela Hammes Rodrigues, no Programa de Pós-graduação em Linguística da UFSC.
} 


\section{INTRODUÇÃO}

A noção de dialogismo é um dos conceitos mais profícuos da teoria bakhtiniana da linguagem, além de ser o centro a partir do qual outros conceitos da teoria se desenvolvem (BRAIT, 2006; BRANDIST, 2012; FARACO, 2009; GERALDI, 2010; PONZIO, 2009; 2010). Com base nos escritos do Círculo de Bakhtin e de pesquisas contemporâneas sob o escopo da Análise Dialógica de Discurso $^{2}$, objetivamos apresentar uma análise das relações dialógicas e dos tons avaliativos que se engendram no funcionamento do gênero carta de conselhos, publicado em revistas online.

Para tanto, selecionamos trinta (30) exemplares do gênero publicados nas seguintes revistas, em suas versões virtuais: Claudia, Nova e Veja, procurando entender a confluência semântico-axiológica entre os já-ditos e os pré-figurados e os movimentos avaliativos (tons) na construção discursiva desse gênero. Para tanto, nosso trabalho organiza-se da seguinte forma: a seção de introdução, uma seção teórica sobre a noção de relações dialógicas, uma seção teórica sobre a noção de valoração, uma seção sobre metodologia, uma seção apresentando a análise dos dados e a seção de considerações finais.

\section{A NOÇÃO DE RELAÇÕES DIALÓGICAS NOS ESCRITOS DO CÍRCULO DE BAKHTIN}

A elaboração da noção de relações dialógicas nos escritos do Círculo de Bakhtin, é delineada explicitamente desde a obra Marxismo e Filosofia da Linguagem (BAKHTIN (VOLOCHÍNOV), 2006[1929]), na qual a questão da interação verbal é apresentada como centro na constituição das relações intersubjetivas, possibilitando a construção de sentido e de valores nessas relações e o diálogo em seu sentido mais amplo (BRAIT, 2006; BRANDIST, 2012; FARACO, 2009). Nessa mesma obra, Bakhtin (Volochínov) (2006[1929]) procura, dentre outros aspectos, discutir a relação entre os sujeitos do discurso - a alteridade -, tida como o princípio estruturador das relações dialógicas. Amorim (2004) explica que a alteridade marca as fronteiras do enunciado, permitindo, por conseguinte, a passagem da palavra ao outro. É esse (relativo) acabamento, segundo a autora, que permite a resposta de outrem.

Brait (2006, p. 28-29) esclarece que a presença do outro é uma das questões fundacionais no estudo das relações dialógicas, "interferindo nas noções de sujeito, de autoria, de texto e de discurso." Da mesma forma, Geraldi (2005) ressalta que o processo social de produção da linguagem é sempre um processo que demanda alteridade. "E essas 'alteridades' não são sujeitos ou individualidades soltas no mundo, mas [...] se constroem nos usos da linguagem (...) historicamente mutáveis." (GERALDI, 2005, p. 78, grifos do autor).

Com isso, podemos entender que é na alteridade que os indivíduos se constituem, em relações sócio-historicamente situadas. Constituímo-nos e transformamo-nos sempre em relação ao/com o outro, em encontros, ou seja, na interlocução. Nessa direção, “[...]

\footnotetext{
2 Consideramos um campo de estudos em Linguística Aplicada constituído por pesquisadores, interlocutores atuais do Círculo de Bakhtin.
} 
dialogia e alteridade definem o ser humano, uma vez que é impossível pensar no homem fora das relações que o ligam a outrem..." (BARROS, 2001, p. 30). Entretanto, mesmo tendo em Marxismo e Filosofia da Linguagem uma discussão inicial, é nos capítulos "O discurso em Dostoiévski", de Problemas da Poética de Dostoiévski e em "O problema do texto na Linguística, na Filologia e em outras Ciências Humanas", em Estética da Criação Verbal que, de fato, encontramos as primeiras definições explícitas do conceito de relações dialógicas:

As relações dialógicas são de índole específica: não podem ser reduzidas a relações meramente lógicas (ainda que dialéticas) nem meramente linguísticas (sintático-composicionais). Elas só são possíveis entre enunciados integrais de diferentes sujeitos do discurso [...]. Onde não há palavra, não há linguagem e não pode haver relações dialógicas; estas não podem existir entre objetos ou entre grandezas lógicas (conceitos, juízos, etc.). As relações dialógicas pressupõem linguagem, no entanto, elas não existem no sistema da língua [...]. As relações dialógicas são relações (semânticas) entre toda a espécie de enunciados na comunicação discursiva. Dois enunciados, quaisquer que sejam, se confrontados em um plano de sentido [...] acabam em relação dialógica. (BAKHTIN, 2003[1979], p. 323)

A partir disso, Bakhtin (2003[1979]) entende que as relações dialógicas, diferem radicalmente de todas as relações linguísticas entre elementos seja do sistema da língua, seja dos textos isolados. Bakhtin (2008[1929]) pontua que as relações dialógicas são, de fato, essencialmente extralinguísticas, e com isso não devem ser separadas do campo do discurso. $\mathrm{O}$ autor explica que os enunciados nascem do ponto de contato com a realidade concreta e nas condições de uma situação de interação real. Assim, as relações dialógicas que se constroem entre os enunciados se constituem sob as mesmas condições dos enunciados (GERALDI, 2010; PONZIO, 2010). O autor assim esclarece,

$\mathrm{Na}$ linguagem, enquanto objeto da linguística, não há e nem pode haver quaisquer relações dialógicas: estas são impossíveis entre os elementos da língua [...] ou entre os elementos do texto num enfoque rigorosamente linguístico deste [...]. Assim, as relações dialógicas são extralinguísticas. Ao mesmo tempo, porém, não podem ser separadas do campo do discurso, ou seja, da língua enquanto fenômeno integral concreto. (BAKHTIN, 2008[1929], p. 208-209).

Como podemos ver, para o autor, as relações dialógicas só ocorrem no campo da vida da linguagem, no campo do discurso. Bakhtin (2003[1979]) ainda pontua que toda a vida da linguagem, seja qual for sua esfera de uso (cotidiana, artística, científica, etc.) está impregnada de relações dialógicas. E como pertencentes ao campo do discurso, as relações dialógicas são apenas possíveis entre enunciações integrais ou tomados como tais pelos interlocutores (BAKHTIN, 2008[1929]). Os enunciados não são indiferentes entre si, pois uns conhecem os outros, relacionam-se com os outros, constituem-se em relação aos outros de forma dialógica. Em realidade, segundo o autor, todo enunciado sempre responde de uma forma ou de outra aos enunciados do outro que o antecederam. Em outras palavras, “[...] cada enunciado é pleno de ecos e ressonâncias de outros enunciados com os quais está ligado pela identidade da esfera da comunicação discursiva..." (BAKHTIN, 2003[1979], p. 297). 
A partir disso, entendemos que os enunciados podem ser considerados como respostas aos enunciados precedentes de uma determinada esfera social. Para o autor, devemos entender que o enunciado ocupa uma posição (axiológica) definida em uma dada esfera da comunicação, em uma dada questão, em um dado assunto. Como consequência, torna-se impossível alguém definir sua posição sem correlacioná-la com outras posições. Bakhtin (2003[1979], p. 297) ainda explica que essa reação-resposta em face dos enunciados de outrem pode ser construída/constituída por diferentes formas.

Assim, podemos compreender que, em termos bakhtinianos, os elementos da língua dentro do seu próprio sistema ou na estruturação interna de um dado texto não podem entrar em relações dialógicas. Contudo, visões de mundo, pontos de vista, vozes ${ }^{3}$ sociais, dialetos, estilos de linguagem podem entrar efetivamente em relações dialógicas, desde que materializados nos enunciados (como discursos). Para o autor, a relação com o sentido e com sua compreensão é sempre dialógica. Portanto, além de serem relações extralinguísticas, as relações dialógicas são relações de sentido entre enunciados.

Além disso, podemos entender que cada enunciado é pleno de ressonâncias e ecos de outros enunciados, de enunciados do outro. Para Bakhtin (2003[1979]), os enunciados não são indiferentes uns com os outros, mas se conhecem e se atravessam mutuamente; e é justamente esse atravessamento de reflexos mútuos que determina seu caráter. $\mathrm{O}$ autor afirma que o enunciado, dialogicamente constituído e orientado, deve ser concebido como uma resposta aos enunciados precedentes, os já-ditos, e aos subsequentes, os pré-figurados, à medida que "[...] o enunciado entra em confronto de valores, ideias, posições com outros enunciados, rejeitando-os, confirmando-os, completando-os, baseando-se neles, subentendendo-os como conhecidos, de certo modo os levando em conta." (BAKHTIN, 2003[1979], p. 297).

Em outras palavras, todos os enunciados são plenos de palavras dos outros, em diferentes graus de assimilação, de alteridade, de aperceptibilidade e de relevância. "Essas palavras dos outros trazem consigo a sua expressão, o seu tom valorativo que assimilamos, reelaboramos e reacentuamos." (BAKHTIN, 2003[1979], p. 295). Por essa razão, o enunciado é pleno de tonalidades dialógicas, e sem considerá-las, é impossível entendê-lo. Bakhtin (1998[1975]; 2003[1979]; 2008[1929]) nos lembra que as relações de sentido são possíveis não apenas entre enunciados integrais, como dito acima, mas também (a) em qualquer parte significante do enunciado; (b) entre estilos de língua, dialetos sociais e (c) "no enunciado como um todo, em relação as suas partes separadas e em relação a uma só palavra em seu interior" (FARACO, 2009, p. 67), desde que tomados como pontos de vista sobre o mundo, representando enunciados integrais. $\mathrm{O}$ autor assim esclarece essa questão:

[...] cada enunciado é pleno de variadas atitudes responsiva a outros enunciados de dada esfera da comunicação discursiva. Essas reações têm diferentes formas: os enunciados dos outros podem ser introduzidos diretamente no contexto do enunciado; podem ser introduzidas somente palavras isoladas ou orações que, neste caso,

\footnotetext{
${ }^{3}$ Entendemos voz, na perspectiva bakhtiniana, como um complexo semântico-axiológico-ideológico de dizer, posicionar-se e compreender o mundo (MORSON; EMERSON, 2008).
} 
figurem como representantes de enunciados plenos e, além disso, enunciados plenos e palavras isoladas podem conservar a sua expressão alheia, mas não podem ser reacentuados (em termos de ironia, de indignação, reverência, etc.); os enunciados dos outros podem ser recontados com um variado grau de reassimilação [...] $\mathrm{O}$ enunciado é pleno de tonalidades dialógicas e sem levá-las em conta é impossível entender até o fim o estilo de um enunciado. (BAKHTIN, 2003[1979], p. 299, grifos do autor).

Quanto às relações dialógicas com qualquer parte significante do enunciado, podemos entender que estas podem consubstanciar no interior do enunciado, mesmo no interior de uma determinada palavra, desde que possamos compreender a relação de sentido, de projeções axiológicas, de colisão de vozes que saturam essa palavra ou parte do enunciado, que criam limites internos no enunciado, destacando as vozes, ou seja, o discurso do autor do enunciado e o discurso do enunciado citado/relatado/mencionado.

Por outro lado, como mencionado anteriormente, as relações dialógicas são também possíveis entre dialetos sociais e estilos da língua, desde que possamos encontrar nessas relações efeitos semânticos, como "[...] cosmovisões de linguagem de certo tipo..." (FARACO, 2009, p. 67). Por fim, as relações dialógicas são também possíveis entre partes do enunciado ou no enunciado como um todo. Bakhtin (2008[1929]) ainda ressalta que em uma abordagem ampla das relações dialógicas, poderíamos afirmar que estas "são possíveis também entre outros fenômenos conscientizados desde que estes estejam expressos numa matéria sígnica.” (p. 211).

Em conclusão, as relações dialógicas são relações discursivas de sentido, isto é, relações que fazem parte da natureza da vida concreta da linguagem. Direcionamo-nos, neste momento, após as discussões sobre as relações dialógicas, para a seção sobre a noção de valoração nos escritos do Círculo.

\section{A NOÇÃO DE VALORAÇÃO NOS ESCRITOS DO CÍRCULO DE BAKHTIN}

Bakhtin (2010[1986]) afirma que todos os atos do sujeito estão sempre sendo atravessados por tons emotivo-volitivos. Para o autor, todo sujeito sempre enuncia atitudes avaliativa sobre si e sobre o outro. Pelo simples fato de agir, enquanto sujeito único e singular, este entra em relações volitivas com o mundo.

A esse respeito, Bakhtin (2010[1986]) afirma que, ao separamos abstratamente o conteúdo da experiência do seu real evento de vivência, o conteúdo se apresenta absolutamente indiferente a respeito do valor atribuído no ato experienciado. Contudo, para tornar-se realmente realizado e experienciado, o conteúdo, incorporado ao ser historicamente instituído, precisa ser atravessado por entoações emotivo-volitivas. Para o autor, "[...] o verdadeiro pensamento que age é pensamento emotivo-volitivo, é pensamento que entoa e tal entoação penetra de maneira essencial em todos os momentos conteudísticos do pensamento..." (BAKHTIN, 2010[1986], p. 87).

Assim, o matiz valorativo dá o caráter do evento. O tom emotivo-volitivo que envolve o conteúdo inteiro do sentido é o mesmo que o relaciona com o existir do evento singular. 
Entendemos que o sistema de valoração do sujeito, em sua eventicidade singular, deve ser uma posição construída nos limites do seu existir.

A ligação entre o conteúdo dos atos vivenciados e seu tom emotivo-volitivo não são de ordem causal, mas entrelaçados na trama histórica das experiências únicas do sujeito. Dessa forma, dentre outras possíveis relações entre o conteúdo da experiência e a sua valoração, para Bakhtin (2010[1986], p. 88), “[...] um pensamento pode ser entrelaçado na trama da minha viva consciência real emotivo-volitiva por razões completamente estranhas, que não tenham nenhuma relação necessária com o aspecto de conteúdosentido do pensamento dado." Com isso, compreendemos que um tom emotivo-volitivo não se refere estritamente ao conteúdo como tal, mas na sua correlação entre o sujeito e a eventicidade do seu ato.

Além disso, a projeção de valor que abarca e perpassa todo existir-evento singular não é uma reação inata ao ser ou uma reação psíquica passiva, mas uma orientação moralmente validada e responsavelmente ativa. Com isso, as projeções valorativas são movimentos de uma consciência responsavelmente consciente, que "transforma uma possibilidade na realidade de um ato realizado, de um ato de pensamento, de sentimento, de desejo, etc." (BAKHTIN, 2010[1986], p. 91). Segundo Bakhtin (2010[1986]), com o tom emotivo-volitivo, todo sujeito indica exatamente o momento do seu ser ativo na experiência vivida, isto é, o sujeito age e constrói valores para esse agir no evento. Bakhtin (2010[1986]) denomina esse estágio de caráter volitivorealizador, à medida que o sujeito experiência seu ato e atribui-lhe um caráter valorativo-sensorial (BAKHTIN, 2010[1986], p. 91). Assim, o autor nos esclarece que

O momento de atuação do pensamento, do sentimento, da palavra, de uma ação, é precisamente uma disposição minha ativamente responsável - emotivo-volitiva em relação à situação na sua totalidade, no contexto de minha vida real, unitária e singular. (BAKHTIN, 2010[1986], p. 91-92).

Nesse sentido, Bakhtin (2010[1986]) afirma que viver significa posicionar-se em relação a valores. O conteúdo da experiência direta de sua vivência real, ao tornar-se realmente realizado e, por conseguinte, incorporado ao ser histórico do conhecimento, precisa entrar em uma ligação direta com a valoração, posto que, "somente como valor efetivo ele é por mim experimentado (pensado), isto é, somente posso pensá-lo em tom emotivo-volitivo." (BAKHTIN, 2010[1986], p. 87). Assim, explica Bakhtin que

Esse conteúdo não cai, de fato, na minha cabeça por acaso, como um meteoro de outro mundo, ficando fechado e impenetrável, sem infiltrar-se no tecido único do meu vivo pensar-experimentar emotivovolitivo como seu momento essencial. Nenhum conteúdo seria realizado, nenhum pensamento seria realmente pensado, se não se estabelecesse um vínculo essencial entre o conteúdo e o seu tom emotivo-volitivo, isto é, o seu valor realmente afirmado por aquele que pensa. Viver uma experiência, pensar um pensamento, ou seja, não estar, de modo algum, indiferente a ele, significa antes afirmá-lo de uma maneira emotivo-volitiva. (BAKHTIN, 2010[1986], p. 87). 
Para o autor, o ato é sempre um ato emotivo-volitivo, pois os atos são atravessados por entoações que penetram em todos os seus momentos conteudísticos. O tom emotivovolitivo abarca todo o conteúdo do ato e o relaciona com o existir-evento singular, isto é, todo ato, em sua singularidade, é orientado por tons emotivo-volitivos. "A experiência real de um vivido possível é precisamente a sua inserção, a sua colocação em comunhão com o existir-evento singular." (BAKHTIN, 2010[1986], p. 87). Para Bakhtin (2010[1986]), o tom emotivo-volitivo interrompe a autossuficiência do conteúdo do ato, incorporando-o no evento singular e único. Com isso, o tom emotivovolitivo "não é uma construção mecânica ou abstrata. Com o tom emotivo-volitivo indicamos exatamente o momento do meu ser ativo na experiência vivida, o vivenciar da experiência como minha." (BAKHTIN, 2010[1920/1924]).

Em adição à discussão do existir único e seu tom emotivo-volitivo, Bakhtin discute a relação entre valoração e ideologia. Bakhtin (Volochínov) (2006[1929], p. 45) afirma que todo signo ideológico é marcado pelo horizonte social de uma época e de um grupo social determinado. Os signos são determinados pelas formas de interação social; seu conteúdo é determinado tanto pelas condições sociais de interação quanto pelos índices sociais de valor. Assim, em cada etapa de desenvolvimento da sociedade, encontram-se grupos de objetos determinados que acabam recebendo valores particulares. Cada objeto, para que receba valores, e, por conseguinte, desencadeie uma reação semióticoideológica, é indispensável que esteja ligado às condições socioeconômicas do referido grupo.

A partir disso, podemos entender que todos os índices sociais de valor são ideologicamente construídos, mesmo que enunciado por indivíduos em seus atos singulares e únicos, pois constituem projeções de valor com pretensões ao consenso social, "e apenas em nome deste consenso é que eles se exteriorizam no material ideológico." (BAKHTIN (VOLOCHÍNOV), 2006[1929], p. 46). Dessa forma, para o autor, todo signo ideológico possui sempre um índice social de valor.

Bakhtin (VOLOCHÍNOV) (2006[1929]) ressalta que todos os índices sociais de valor dos signos ideológicos chegam de forma semelhante à consciência individual. Na consciência, esses índices se tornam individuais, mas a fonte de sua projeção se encontra, contrariamente, no horizonte social. Assim, para o autor, o índice de valor é de natureza interindividual, ou seja, fundado no mundo exterior, no qual os atos se orientam no participar singular e na relação com o outro.

Com isso, uma vez estabelecida a relação constitutiva entre ideologia e signo/linguagem, observamos a questão da dimensão valorativa dos enunciados e da sua materialização na entonação. Os enunciados, que materializam os discursos, apresentam sempre uma dimensão axiológica e expressam um posicionamento social. Desse modo, qualquer enunciado é, "na concepção do Círculo, sempre ideológico - para eles [membros do Círculo], não existe enunciado não-ideológico. E ideológico em dois sentidos: qualquer enunciado se dá numa esfera de uma das ideologias [...] e expressa sempre uma posição avaliativa ...” (FARACO, 2009, p. 46-47).

O que o Círculo procura esclarecer é que o enunciado é concebido não apenas como uma unidade de comunicação, mas como uma unidade de sentido axiologicamente 
constituída na situação interativa. Além disso, Bakhtin (2003[1979]) explica que o enunciado, seu estilo e sua composição são determinados pelo elemento semânticoobjetal e por seu tom expressivo, isto é, "[...] pela relação valorativa do falante com o elemento semântico-objetal do enunciado...” (p. 296). Assim, para o autor, todo enunciado possui uma orientação valorativa, um determinado acento apreciativo. A valoração, portanto, juntamente com as demais instâncias da situação extraverbal, possibilita a compreensão dos juízos de valor que organizam as ações de um dado grupo social.

Segundo Rodrigues (2001), esse vínculo entre o enunciado e a situação social concretiza-se pela entonação. "Através dela, o discurso se orienta para fora dos seus limites verbais e entra em contato com a vida sócio-ideológica. Ela se situa na fronteira da vida social e da parte verbal do enunciado, marcando a atitude valorativa [...]. Pela entonação o falante se engaja socialmente e toma posição ativa em relação a certos valores.” (RODRIGUES, 2001, p. 27). Por essa razão, para Bakhtin,

Um enunciado isolado e concreto sempre é dado num contexto cultural e semântico-axiológico (científico, artístico, político, etc.) ou no contexto de uma situação isolada da vida privada; apenas nesses contextos o enunciado isolado é vivo e compreensível. (BAKHTIN, 1998[1975], p. 46).

A partir disso, podemos entender que os juízos de valor têm na entonação a sua expressão mais pura, que se situa nos limites entre o plano verbal e o extraverbal. Rodrigues (2001) explica que o fato da situação social determinar o enunciado não deve conduzir à compreensão de que os enunciados refletem passivamente a situação de interação. $O$ enunciado conclui uma situação social, representando sua solução valorativa. Com isso, podemos entender que a entonação não apenas estabelece um vínculo entre o enunciado e seu contexto, mas situa o enunciado nos limites entre o verbal e o extraverbal. A entonação, como expressão da atitude valorativa do sujeito é, portanto, uma propriedade constitutiva do enunciado. Assim, a entonação pode ser entendida como a materialização da avaliação social.

Em conclusão, a valoração é definida como uma ligação constitutiva entre o enunciado e sua situação de interação, e também como a valoração social da própria situação, responsável pelo sentido do enunciado. Portanto, a valoração "[...] está na fronteira entre a vida e o aspecto verbal do enunciado; (...) ela dá a qualquer coisa linguisticamente estável o seu momento histórico vivo, o seu caráter único." (BAKHTIN, 1926, p. 09).

Direcionemos nossa voz, nesse momento, para a seção sobre nosso caminho metodológico.

\section{A ROTA METODOLÓGICA E A APRESENTAÇÃO DOS DADOS}

Ao percorrermos o conjunto de textos das obras de Bakhtin e do Círculo não encontramos, em nenhum dos textos, uma sistematização de um método científico propriamente dito, com parâmetros e categorias de análise estabelecidos a priori para 
serem seguidos durante a pesquisa. Para Faraco (2009), o pesquisador da obra do Círculo depara-se com grandes diretrizes que podem ser seguidas para a construção de um entendimento mais amplo das realidades em estudo. Dessa forma, concordamos com Amorim (2004) e Faraco (2009) que afirmam que as investigações bakhtinianas identificam-se com uma tradição hermenêutica dos estudos humanos, uma tradição que compreende que o fazer ciência em Ciências Humanas se concretiza por gestos interpretativos, por uma contínua construção de sentidos e não por caminhos objetivomatemáticos, percurso essencialmente positivista. Em termos de filosofia da ciência, "podemos dizer, então, que Bakhtin se vinculava a um pensamento que costuma operar sobre o pressuposto de uma distinção de fundo entre as ciências naturais e as ciências humanas." (FARACO, 2009, p. 41).

Além disso, para Amorim (2004), Brait (2006) e Faraco (2009), um dos indicadores mais óbvios da ausência de um projeto metodológico de pesquisa fixo e construído de antemão está no fluxo terminológico que Bakhtin apresenta ao longo de seu conjunto de textos e em suas análises, como em Marxismo e Filosofia da Linguagem e em Problemas da Poética de Dostoiévski, Bakhtin e o Círculo não procuram apresentar categorias definidas à luz da "objetividade calculável" (FARACO, 2009), mas rotas interpretativas preliminares, sugestivas e provisórias. É nessa perspectiva que procuramos compreender os pressupostos bakhtinianos para os estudos da linguagem, mais especificamente, para o caminho a percorrer nesta pesquisa. Como explica Brait (2007):

[...] o maior ensinamento de Bakhtin [é] a atitude diante da linguagem que consiste não na aplicação de conceitos pré-estabelecidos a um corpus imobilizado pelas lupas do analista, mas uma atitude dialógica que permite que os conceitos sejam extraídos do corpus, a partir de um constante diálogo entre a postura teórico-metodológica e a dinâmica das atividades, da linguagem e da rica parceria por elas estabelecidas. [...] para Bakhtin, não há a possibilidade de pura e simplesmente operacionalizar conceitos pré-estabelecidos, na medida em que não acreditava que fosse essa a função das Ciências Humanas, aí incluídos os estudos da linguagem. Seu pensamento, como atitude diante do conhecimento, significa um contato dialógico com o corpus selecionado, um continuum cujo acabamento, mesmo que visível, é sempre inconcluso, participa de uma dinâmica permanente que interroga permanentemente o analista e o obriga a buscar, até mesmo em outras disciplinas, conceitos, noções, que possam ajudar na análise da complexa relação existente entre as atividades humanas e as atividades discursiva a elas afeitas. (BRAIT, 2007, p. 29-31),

Em outras palavras, no caminho metodológico bakhtiniano, não há categorias de análise a priori aplicáveis de forma sistemática a textos, discursos, gêneros, com a finalidade de construir uma análise acerca do uso situado da língua. Em Bakhtin, há, na verdade, uma arquitetônica das diferentes formas de conceber o enfrentamento dialógico da linguagem, que se constituem de movimentos teórico-metodológicos multifacetados. De fato, cabe ao pesquisador desbravar esse caminho, construindo, por conseguinte, uma postura dialógica diante de seu objeto discursivo. "A pertinência de uma perspectiva dialógica se dá pela análise das especificidades discursivas constitutivas de situações em 
que a linguagem e determinadas atividades se interpenetram e se interdefinem [...]" (BRAIT, 2006, p. 29).

Sob essa perspectiva, nessa pesquisa, procuramos analisar o gênero carta de conselhos a partir dos textos que o materializam, vistos e analisados como enunciados sóciohistoricamente situados. Nessa orientação, nosso estudo baseia-se no método sociológico de estudo da linguagem do Círculo de Bakhtin. Bakhtin (Volochínov) (2006[1929], p. 128-129), em Marxismo e Filosofia da Linguagem, apresenta as etapas metodológicas para o estudo da língua, ou outros aspectos da comunicação discursiva como os gêneros do discurso - à luz de um percurso sócio-histórico. São elas:

1. As formas da língua e os tipos de interação verbal em ligação com as condições concretas em que se realiza;

2. As formas das distintas enunciações, dos atos de fala [gêneros do discurso] isolados, e, ligação estreita com a interação de que constituem os elementos, isto é, as categorias de atos de fala [os gêneros do discurso] na vida e na criação ideológica que se prestam a uma determinação pela interação verbal;

3. A partir daí, exame das formas da língua na sua interpretação linguística habitual. (BAKHTIN (VOLOCHÍNOV), 2006[1929], p. 128-129).

Para nossa análise, selecionamos trinta (30) textos do gênero carta de conselhos, de três revistas online e de circulação nacional, sendo dez (10) de cada uma das revistas. Para identificação e referência ao longo deste trabalho, os textos receberam um código, o qual é composto por uma sigla e um número. As siglas CRC, CRN e CRV foram utilizadas para identificar as cartas das revistas Claudia, Nova e Veja, respectivamente, e o número para identificar o texto que está sendo analisado. Por exemplo, CRC\#01 significa carta da revista Claudia número 01. Além disso, apresentamos a carta intercalada do reclamante com fonte em negrito e o restante da carta de conselhos com fonte sem destaque, na mesma forma como as revistas publicam as cartas de conselhos.

No processo de escolha e seleção das cartas que fizeram parte de nossos dados, optamos por aquelas que apresentassem objetos temáticos ${ }^{4}$ diversos, isto é, buscamos cartas de conselhos que tematizassem objetos discursivos diferentes, como família, sexo, relações pessoais, relações profissionais, saúde, profissão, alimentação, moda, dentre outros, procurando uma heterogeneidade de conteúdos. Essa opção por selecionar um conjunto de dados que apresentasse diferenças temáticas justifica-se por acreditarmos que, dessa heterogeneidade, poderíamos desenvolver um estudo mais amplo do gênero carta de conselhos, viabilizando seu estudo a partir de textos de linhas editoriais diferenciadas e de objetos diversificados. Como exemplificação dos dados, vejamos três (3) exemplares das cartas de conselhos publicadas nas revistas em versão online:

\footnotetext{
${ }^{4}$ Entendemos que os gêneros do discurso refletem as condições específicas e as finalidades de cada esfera social por meio da relativa regularidade do objeto temático, como também do estilo e da construção composicional. Em relação ao conteúdo (objeto) temático, especificamente, compreendemos que se refere ao domínio de sentido de que se ocupa o gênero; a maneira como o gênero seleciona elementos da realidade e como os trata discursivamente (MORSON; EMERSON, 2008).
} 


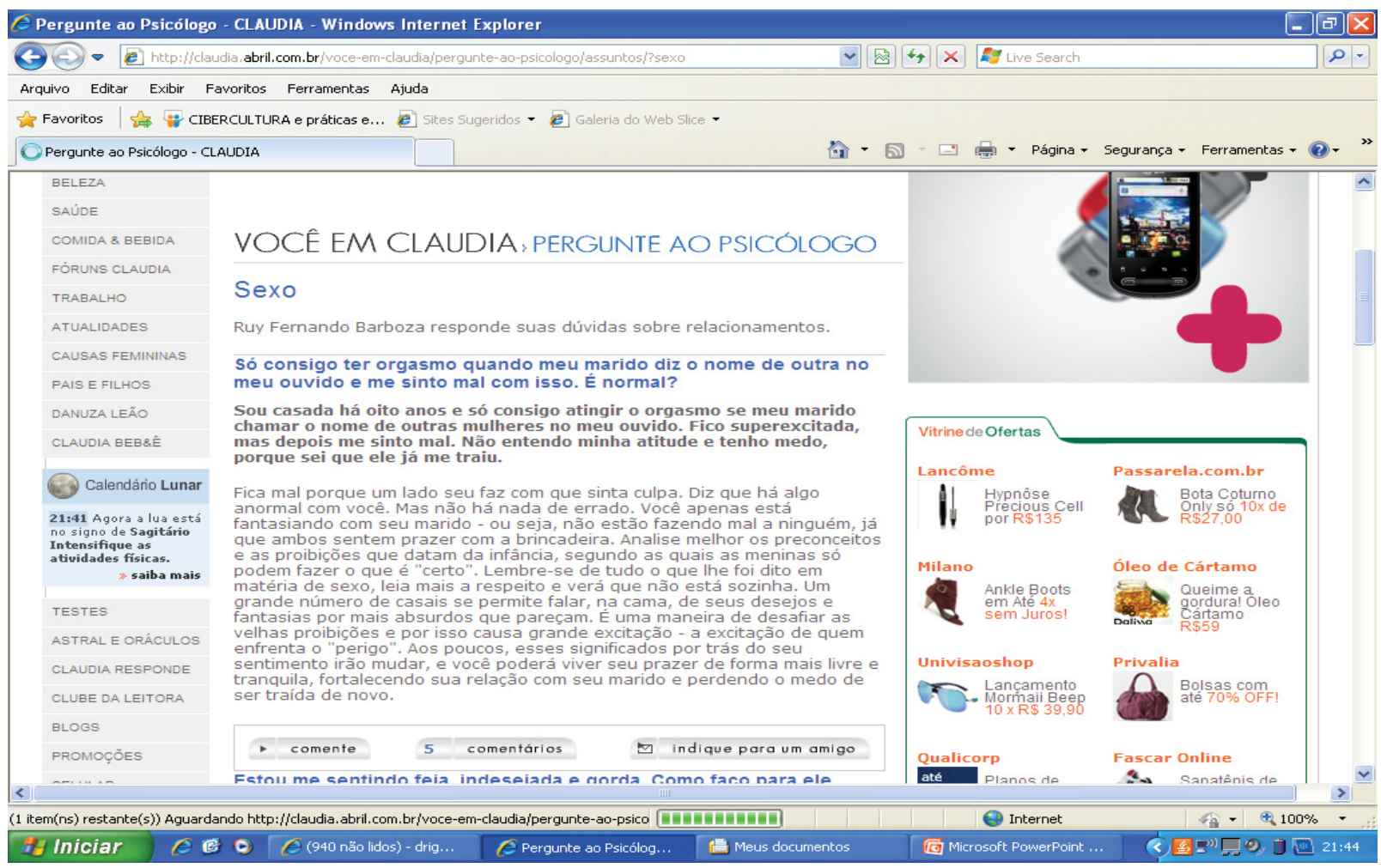

Figura 1: A carta de conselhos na revista Claudia.

Fonte: $<$ http://claudia.abril.com.br/>. Acesso: 30 maio 2011.

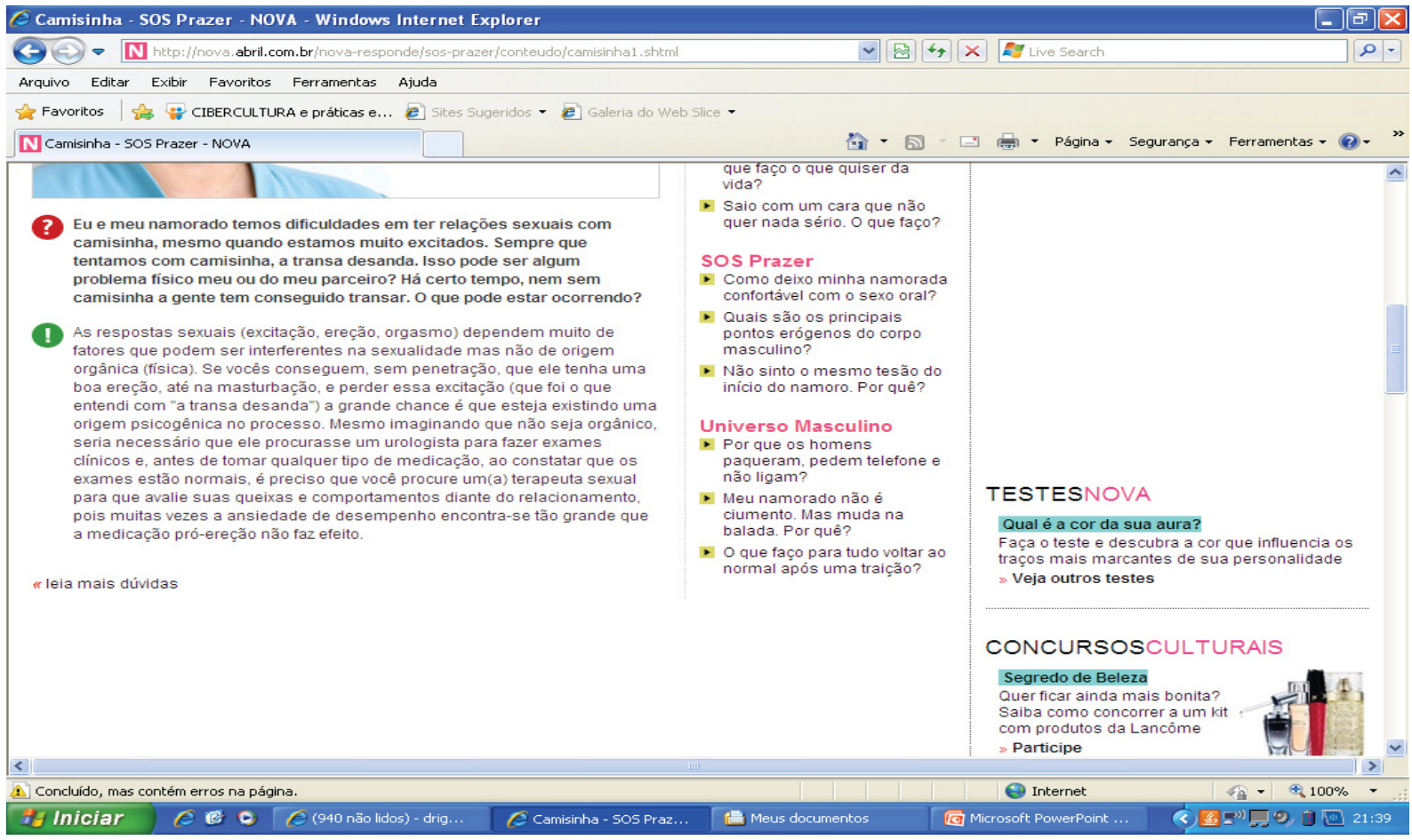

Figura 2: A carta de conselhos na revista Nova.

Fonte: $<$ http://mdemulher.abril.com.br/revistas/nova/>. Acesso: 30 maio 2011. 


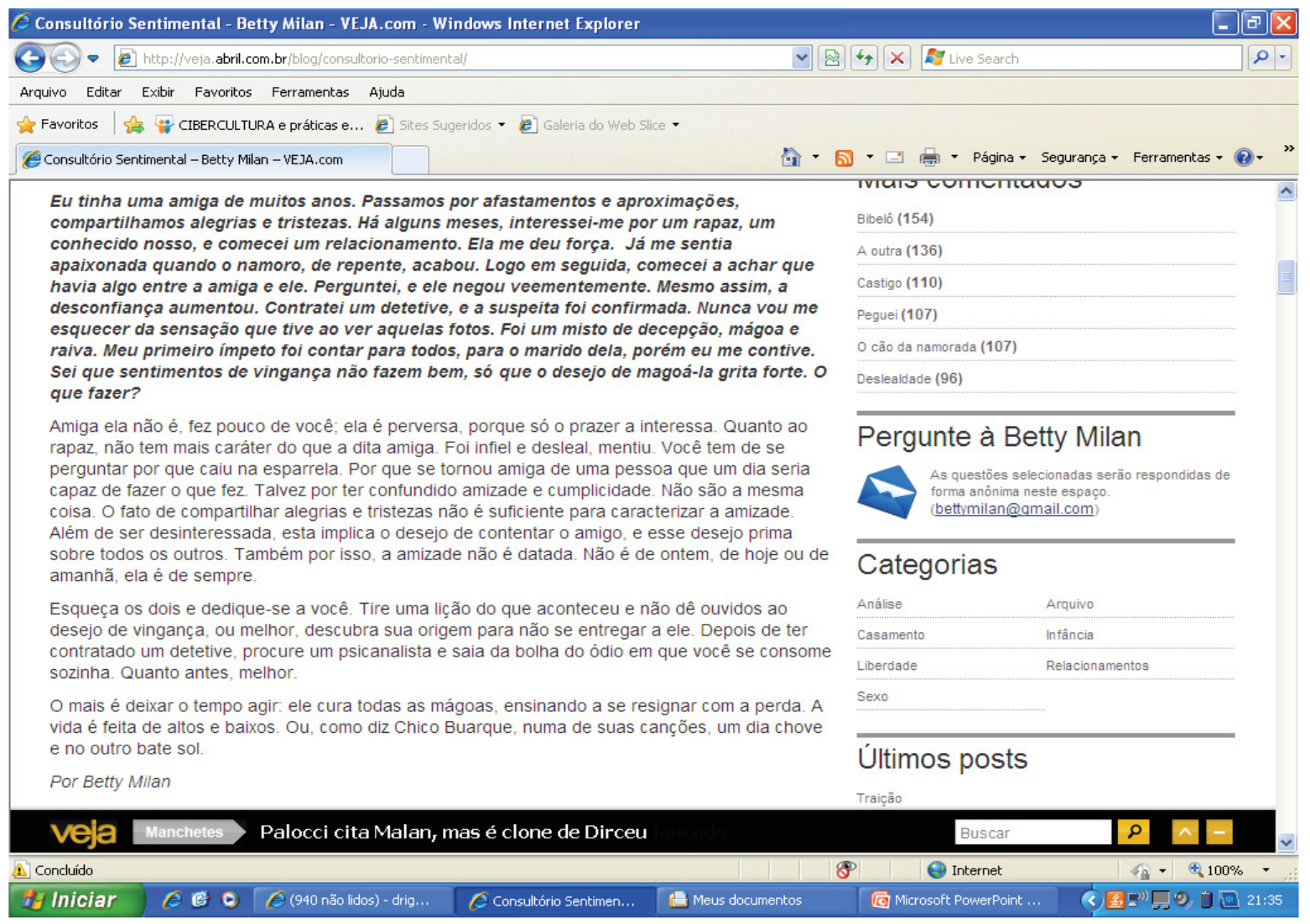

Figura 3: A carta de conselhos na revista Veja.

Fonte: <http://veja.abril.com.br/>. Aceso: 30 maio 2011.

\section{O ENCONTRO DE DISCURSOS OUTROS NO ENUNCIADO DO CONSELHEIRO/ARTICULISTA: A CONFLUÊNCIA ENTRE POSIÇÕES VERBO-AXIOLÓGICAS}

Para Bakhtin (2008[1929]), como já discutido, as relações com o enunciado do outro podem penetrar no âmago do enunciado, chocando-se dialogicamente duas vozes; podem se realizar na relação entre dialetos sociais, estilos de linguagem, desde que estas relações sejam compreendidas como certa cosmovisão da linguagem; e, por último, as relações dialógicas são possíveis na própria enunciação como um todo, com partes isoladas do todo ou com apenas uma palavra isolada nele (desde que represente o todo de um enunciado). Nesta seção, nossa discussão centra-se na reenunciação de discursos já-ditos e de discursos pré-figurados nas respostas do conselheiro/articulista ${ }^{5}$. Nosso foco, dessa forma, está nas relações entre enunciados integrais ou mesmo com partes isoladas (mas entendidas como enunciados integrais), procurando perceber onde se chocam dialogicamente duas posições semântico-valorativas (verbo-axiológicas). Sobre o enquadramento do discurso do outro, Bakhtin explica que

[...] por maior que seja a precisão com que é transmitido, o discurso de outrem incluído no contexto sempre está submetido a notáveis transformações de significado. O contexto que avoluma a palavra de

\footnotetext{
${ }^{5}$ Nomeamos como reclamante quem envia a carta às revistas, e conselheiro/articulista quem as responde.
} 
outrem origina um fundo dialógico cuja influência pode ser muito grande. Recorrendo a procedimentos de enquadramentos apropriados, pode-se conseguir transformações notáveis de um enunciado alheio, citado de maneira exata. $\mathrm{O}$ polemista inescrupuloso e hábil sabe perfeitamente que fundo dialógico convém dar às palavras do adversário, citadas com fidelidade, a fim de lhes alterar o significado. [...] A palavra alheia introduzida no contexto do discurso estabelece com o discurso que o enquadra não um contexto mecânico, mas uma amálgama química (no plano do sentido e da expressão); o grau de influência mútua do diálogo pode ser imenso (BAKHTIN, 1998[1975], p. 141).

Inicialmente, podemos dizer que é a carta do reclamante a primeira reenunciação e o primeiro enquadramento do discurso do outro na carta de conselhos. Contudo, além da intercalação da carta do reclamante, entendemos que o conselheiro/articulista, a fim de validar seu ponto de vista, reenuncia outros discursos já-ditos, que funcionam como elos autorais, coautorias discursivas.

Em outras palavras, o conselheiro/articulista interage com enunciados de outrem, como de médicos e cientistas ou de outros conselheiros/articulistas (que escrevem cartas na mesma revista) para validar seus conselhos e, a partir disso, compartilhar a autoria. Com o discurso do outro em sua resposta, o conselheiro/articulista discursiviza uma imagem do outro como aliado, compartilhando a responsabilidade de seu conselho, isto é, cria-se uma aliança ou, por assim dizer, um cooperativismo autoral: o conselheiro/articulista não é o único a se posicionar dessa forma, mas, em consórcio, o outro citado assim se posiciona. Há um suporte enunciativo-discursivo do outro na validação da resposta. $\mathrm{O}$ outro acaba por participar como um coautor, um parceiro na resposta dada ao reclamante.

Entendendo que, na abordagem bakhtiniana, toda autoria ${ }^{6}$ pressupõe uma tomada de posição (BAKHTIN, 2003[1979]; BRAIT, 2007; FARACO, 2006; MORSON; EMERSON, 2008), isto é, todo o sujeito-autor engendra-se em uma relação valorativa com o discurso e é, por conseguinte, esse posicionamento emotivo-volitivo que dá o tom $^{7}$ a esse discurso, podemos entender que o cooperativismo autoral, aqui em discussão, se constitui, essencialmente, como uma confluência entre posições discursivas (posições verbo-axiológicas). Além disso, Faraco (2006) explica que, para o Círculo, a grade força que sustenta as práticas culturais, dentre elas os usos sociais da linguagem, são precisamente as posições socioavaliativas postas numa dinâmica de múltiplas inter-relações responsivas. Com isso, podemos entender que, ao construir diálogos autorais, o conselheiro-articulista constrói seu discurso responsivo por meio de um confronto de posições valorativas (FARACO, 2009), ratificando, por conseguinte, a postulação do Círculo acerca da dinâmica dialógica em torno da alteridade.

Assim, ao se utilizar do discurso do outro para validar seu ponto de vista, o conselheiro/articulista investe nas estratégias de compartilhamento do conselho dado, à

\footnotetext{
${ }^{6}$ Faraco (2006) explica que, para o Círculo, a autoria é entendida como uma posição axiológica, um modo de ver o mundo que guia a construção discursiva e orienta a resposta do outro. O autor é o agente que mobiliza a produção do enunciado.

${ }^{7}$ Ver a próxima seção sobre tons avaliativos.
} 
medida que procura um aliado no outro. $\mathrm{O}$ enquadramento do discurso já-dito de outrem como forma de validar os conselhos, portanto, ratifica a ideia de engajamento e de cooperação do outro na autoria - uma coautoria discursiva - da carta de conselhos. $\mathrm{O}$ discurso já-dito do outro valida o ponto de vista do conselheiro/articulista e autoriza o outro a ser parceiro do conselheiro/articulista nesta empreitada de responder publicamente sobre problemas particulares do reclamante. Vejamos esses resultados de análise nas cartas a seguir:

Ex.: 01 - Tenho um namorado maravilhoso, nosso relacionamento é excelente. Porém, ele me traiu. Confessou a traição, mas implorou para que eu continue com ele. Eu o amo muito, então resolvi dar uma chance, mas está sendo muito difícil aceitar tudo isso. O que vocês me dizem? Para o psiquiatra e colunista de NOVA Paulo Gaudêncio, ele pode voltar a ser fiel, desde que tenha uma motivação. "O instinto sexual precisa de novidade. Sendo assim, ser monógamo frustra uma necessidade natural. E aí, para eu aceitar uma frustração, preciso ter uma compensação. Seu namorado mudará de atitude ao ver vantagem em não passar mais pelo castigo de ser descoberto, em agradar a mulher amada, em investir em uma relação..." O Dr. Gaudêncio acrescenta que o que faz homens comprometidos traírem com tanta facilidade é a certeza da impunidade. Você decidiu dar a ele uma segunda chance. [...] No mais, é importante que o casal avalie a situação e tome essa decisão em conjunto. "Então, o que tem a fazer é superar a história e seguir em frente", aconselha a psicoterapeuta Alina Discepolo Barone. (CRN\#03).

Ex.: 02 - Como peço carinho e atenção ao meu marido? Temos uma ótima vida sexual, mas às vezes me sinto sozinha. Que tal admitir que precisa de carinho? Pare de perder tempo ficando na sua, só para não se mostrar frágil, quando está louca para receber uma massagem ou para deitar no colo do seu amor. Segundo especialistas em relacionamentos, homens nasceram para ajudar - ou seja, se disser do que precisa, ele se prontificará a satisfazê-la. Além do mais, eles costumam demonstrar carinho com atitudes, e não com palavras. Então, repare no jeito dele de ser atencioso. Observe, por exemplo, se tenta animar você ao perceber que está estressada, se nunca se esquece de comprar aquilo de que gosta na ida ao supermercado. (CRN\#07).

Ex.: 03 - Tornei-me uma pessoa que não acredita no amor. Talvez por nunca ter encontrado alguém que me amasse de verdade. Aprendi a me amar e amar os animais, mas, em relação aos homens, esse sentimento não brota mais. Já me apaixonei várias vezes e só sofri com isso. [...] Não corto a relação, não me liberto. Desejo ser livre, conhecer homens apenas para me divertir, sem compromisso, sem me apegar... Só que tenho medo de ficar sozinha. Como faço para realizar o desejo de ser livre? Ter se apaixonado não quer dizer ter amado. $\mathrm{O}$ mais provável é que você não tenha amado ninguém de verdade. [...] Um bom exemplo disso é o romance de Laclos, Ligações Perigosas. Você pode ler ou assistir ao filme - de tão bom, o texto teve mais de uma adaptação para o cinema. O libertino se envolve porque o amor é a nossa vocação primeira, a 
vocação dos mortais. Faz a eternidade soar e assim suspende a morte. Nada nos satisfaz mais. Dai talvez o poema de Drummond:

Que pode uma criatura senão, entre criaturas, amar? Amar e esquecer, amar e mal amar, amar, desamar, amar Sempre, e até de olhos vidrados, amar? (CRV\#05).

$\mathrm{Na}$ carta CRN\#03, a reclamante procura por conselhos sobre a traição de seu parceiro. O parceiro trai, mas pede à reclamante para continuar o relacionamento. A reclamante pretende dar uma segunda chance, mas antes deseja receber conselhos de um "especialista". O conselheiro/articulista, ao responder à remetente, reenuncia os enunciados do psiquiatra e colunista Paulo Gaudêncio ("O instinto sexual precisa de novidade. [...] O Dr. Gaudêncio acrescenta que o que faz homens comprometidos traírem com tanta facilidade é a certeza da impunidade."), e da psicoterapeuta Alina Discepolo Barone. Assim sendo, Dr. Gaudêncio e Alina Barone compartilham com o conselheiro/articulista a responsabilidade pelo conselho dado a partir do elo autoral, que se constrói com o enquadramento de suas vozes no discurso do conselheiro/articulista.

$\mathrm{Na}$ carta CRN\#07, a reclamante solicita ajuda ao conselheiro/articulista para seu relacionamento conjugal e sua procura por carinho e atenção de seu cônjuge. $O$ conselheiro/articulista valida seu ponto de vista introduzindo a voz de um especialista na área, explicando que, tradicionalmente, os homens nasceram para ajudar suas esposas: "Segundo especialistas em relacionamentos, homens nasceram para ajudar ou seja, se disser do que precisa, ele se prontificará a satisfazê-la." Com o enunciado do outro, o conselheiro/articulista valida seu ponto de vista e busca convencer a reclamante a aceitar suas conclusões a respeito do problema apresentado, legitimado por "especialistas" no assunto. Dessa forma, o conselheiro/articulista e os "especialistas em relacionamentos" trabalham discursivamente em conjunto na apresentação do conselho dado para a reclamante. As vozes dos "especialistas em relacionamentos" se conjugam à voz do conselheiro/articulista e todos trabalham colaborativamente.

A carta CRN\#05, por sua vez, traz o problema da reclamante em não conseguir se apaixonar novamente. Ela diz que deseja apenas divertir-se, sem relacionamentos sérios e duradouros. $\mathrm{O}$ conselheiro/articulista reenuncia o enunciado do outro na procura por convencer a reclamante com seus conselhos, validando-os com versos do poeta Carlos Drummond de Andrade. Com isso, o conselheiro/articulista, por meio do enunciado citado de Drummond cria uma parceria autoral no conselho apresentado. O conselheiro/articulista reenuncia a voz de Drummond, não apenas validando seu ponto de vista em relação ao problema da reclamante, como, a partir desse enquadramento, constrói um elo dialógico de autoria entre seu discurso e o discurso do poeta.

A partir disso, podemos entender que a reenunciação do discurso do outro, na carta de conselhos, funciona como um cooperativismo autoral, à medida que $\mathrm{o}$ conselheiro/articulista procura, por meio da voz de outrem, seu enunciado já-dito, não somente o reconhecimento de que seu conselho seja válido, como visa compartilhar a autoria deste. Há, de fato, uma busca por um discurso outro que se conjugue à autoridade discursiva do conselheiro/articulista. O outro compartilha, supostamente, com o conselheiro/articulista da mesma opinião em relação à questão proposta pelo reclamante e ambos, ao final, trabalham cooperativamente para convencer o reclamante. 
Em suma, na confluência de posicionamentos verbo-axiológicos, tecem-se coautorias discursivas.

Além disso, o conselheiro/articulista, a fim de validar seu ponto de vista, enuncia e enquadra discursos pré-figurados (discursos possíveis) do reclamante, que, por sua vez, funcionam como encenações discursivas da (possível) reação-resposta do reclamante em relação ao seu próprio problema, isto é, o reclamante envia seu problema e o conselheiro/articulista responde, utilizando-se de enunciados pré-figurados do reclamante como uma possível forma desejável deste reagir ao problema exposto. Vejamos nas cartas a seguir:

Ex.: 04 - Tenho 34 anos e sonho em ter filhos, mas meu marido já tem três de outro relacionamento e não quer mais. Às vezes, penso em sabotar nosso método contraceptivo e dizer simplesmente que "falhou". Ele adora crianças e tenho certeza de que, depois, ficará tudo bem. É muito desleal da minha parte? Claro que é desleal, né, amiga? A mesma deslealdade que seria se ele fizesse uma vasectomia sem nem consultá-la. Afinal, a vida reprodutiva de um casal é decisão... do casal. Mas, se você quer engravidar e já deixou claro, não tem por que continuar com essa onda de? Nosso método? Quem não quer é ele? Então ele que se cuide, ué. Sugiro avisá-lo: "Olha, querido, eu quero muito engravidar. Se você realmente não quer, fique à vontade, mas quem vai ter que se preocupar com isso agora é você". Não é mais justo? (CRC\#04).

Ex.: 05 - Sou cuidadosa com meu dinheiro: nunca gasto mais do que ganho, programo viagens com antecedência para conseguir bons preços, não compro roupa por modismo. Minhas amigas dizem que sou prevenida demais e insinuam pão-durismo. Fico surpresa, porque considero a minha postura correta. $E$, no fundo, me sinto incomodada com os comentários. Lembra a fábula da formiga e da cigarra? No verão, a primeira trabalhou duro e armazenou mantimentos para o inverno. Sorria e pense: "Que pena, essa gente não sabe o que faz".._Tenho, porém, a impressão de que você guarda dentro de si uma cigarra meio reprimida [...]. (CRN\#01).

No exemplo da carta CRC\#04, temos a reclamante com problemas conjugais, especificamente em relação à (im)possibilidade de ter filhos. O caso é que o marido já possui filhos em outro casamento e não deseja ter mais. A reclamante tem pensado em sabotar os métodos contraceptivos e informar ao seu cônjuge que houve uma falha: "Tenho 34 anos e sonho em ter filhos, mas meu marido já tem três de outro relacionamento e não quer mais. As vezes, penso em sabotar nosso método contraceptivo e dizer simplesmente que 'falhou'." O conselheiro/articulista projeta uma encenação discursiva da possível reação-resposta da reclamante frente ao seu problema: Sugiro avisá-lo: "Olha, querido, eu quero muito engravidar [...]." Em outras palavras, o conselheiro/articulista encena o que a reclamante poderia/deveria fazer em relação ao seu próprio problema, antecipando seu discurso de resposta, procurando convencê-la do conselho dado. 
Já na carta CRN\#01, a reclamante se diz cuidadosa com o seu dinheiro, mas se sente incomodada com os comentários das amigas em relação a sua atitude de extrema preocupação com as finanças. Para responder à questão, o conselheiro/articulista explica a inexistência de simpatias para o caso e sugere que a reclamante mantenha um equilíbrio entre os interesses particulares e as finanças. Ao final de sua resposta, o conselheiro/articulista projeta a possível reação responsiva da reclamante em relação ao problema pessoal que relata, solicitando a ela que sorria e pense: "[...] "Que pena, essa gente não sabe o que faz."

O que podemos entender é que a enunciação do discurso pré-figurado do reclamante na carta de conselhos funciona como uma encenação do discurso do reclamante, isto é, o conselheiro/articulista visa antecipar a reação-resposta do reclamante em relação ao seu próprio problema por meio de projeções de sua [do reclamante] possível contrapalavra. Em outras palavras, na validação dos pontos de vista do conselheiro/articulista por meio da enunciação do discurso pré-figurado do reclamante, o conselheiro/articulista projeta encenações (atos cênico-discursivos) orientadas da reação-resposta deste para seu próprio problema, procurando convencê-lo do aconselhamento dado. Assim, ao procurar responder ao reclamante, orientando-o para o conselho visado, o conselheiro/articulista antecipa o discurso do reclamante, apresentando direcionamentos do que dizer/fazer em relação ao que expõe.

Em termos gerais, observamos que na carta de conselhos, o conselheiro/articulista, com o objetivo de validar seu discurso, ora reenuncia discursos já-ditos, ora enuncia discursos pré-figurados. Com a reenunciação de discursos já-ditos, o conselheiro/articulista constrói elos autorais consubstanciados pela voz do outro. Por outro lado, com a enunciação do discurso pré-figurado do reclamante, constrói encenações discursivas de antecipação da reação-resposta do reclamante em relação ao seu próprio problema. Após a discussão sobre o atravessamento dialógico de posicionamentos valorativos entre enunciados já-ditos e pré-figurados no discurso do conselheiro-articulista, direcionamos nossa discussão para os tons avaliativos que o conselheiro-articulista imprime em seu discurso em relação ao discurso do reclamante.

\section{TONS AVALIATIVOS NO DISCURSO DO CONSELHEIRO-ARTICULISTA}

$\mathrm{Na}$ seção anterior, analisamos o encontro dialógico entre o discurso do conselheiroarticulista e discursos outros, enquanto confluência entre já-ditos e pré-figurados na carta de conselhos. Nesta seção, por sua vez, objetivamos compreender como se constroem os movimentos dialógicos avaliativos do conselheiro/articulista em relação aos problemas do reclamante. Em outras palavras, desejamos responder a questão: como o conselheiro/articulista avalia os problemas expostos pelo reclamante?

Na carta de conselhos encontramos diferentes tons avaliativos, que são construídos por movimentos dialógicos de reação ao enunciado do reclamante. Primeiramente, interpretamos que há um movimento dialógico de avaliação por analogia, ou seja, um tom avaliativo que se apresenta nas cartas por meio de comparações. Vejamos esse movimento nas cartas abaixo: 
Ex.: 06 -Sou cuidadosa com meu dinheiro: nunca gasto mais do que ganho, programo viagens com antecedência para conseguir bons preços, não compro roupa por modismo. Minhas amigas dizem que sou prevenida demais e insinuam pão-durismo. Fico surpresa, porque considero a minha postura correta. $E$, no fundo, me sinto incomodada com os comentários. Lembra a fábula da formiga e da cigarra? No verão, a primeira trabalhou duro e armazenou mantimentos para o inverno. A segunda só se divertiu e, por isso, não teve o que comer no frio. Me parece que você é uma formiga, preocupada em manter a sua despensa sempre cheia -o que eu considero uma postura ajuizada. Como as cigarras não agem assim, sentem uma ponta de inveja na hora do aperto e a acusam de pão-durismo. Se você está tranquila sendo como é, não se abale com as críticas. Sorria e pense: "Que pena, essa gente não sabe o que faz". Tenho, porém, a impressão de que você guarda dentro de si uma cigarra meio reprimida. Não é à toa que, quando as pessoas a chamam de mão-de-vaca, acabam encontrando um cúmplice na sua própria cabeça. Analise se minha tese é verdadeira. Se for, respeite seu jeito formiga de ser, mas adote um pouco do espírito cigarra. Permita-se fazer algo sem juízo de vez em quando. (CRN\#01)

Ex.: 07 -Estou namorando um homem recém-separado. Sei que ele gosta de mim, mas tenho que aturar muitas coisas do falido casamento, como uma caneca cafona com a foto do casal. Ele não está pronto para outra ou só é preguiçoso? Comprar uma casa já usada é sempre um problema, pois trará detalhes do antigo morador. $\mathrm{O}$ importante é você ir fazendo a reforma aos poucos. A arquiteta é você, e o talento para realizar a melhoria não virá de outro lugar. Meu pai era construtor e dizia sempre que é melhor construir que reformar. Mas nada impede que a reforma valha a pena. Uma coisa é certa: vai dar trabalho. Aos poucos e com jeito você vai fazendo as suas mudanças. Se o pedreiro for preguiçoso, dê uma acelerada no andamento. A arquiteta pode exigir. (CRC\#06)

$\mathrm{Na}$ carta CRN\#01, o conselheiro/articulista se dirige à reclamante como "[...] uma formiga preocupada em manter a sua despensa sempre cheia [...]." Ao invés de apresentar diretamente sua avaliação do problema exposto pela reclamante, o conselheiro/articulista se utiliza de procedimentos analógicos na avaliação. Por meio da analogia, avalia a reclamante a partir da relação entre dois universos discursivos: não ser uma "formiga" (cuidadosa demais), mas ser uma "cigarra" (desajuizada, às vezes). O conselheiro/articulista apresenta a analogia construída à luz do universo valorativo da fábula.

Já na carta CRC\#06, semelhante à carta acima, o conselheiro/articulista se dirige à reclamante como uma suposta "arquiteta", fazendo uma analogia entre a reforma da relação e a reforma de uma casa. A reclamante tem problemas com seu namorado recém-separado de outra relação e o conselheiro/articulista avalia a situação da reclamante por meio da analogia: a analogia da reclamante com uma "arquiteta" e seu namorado com um "pedreiro", salientando que "[...] se o pedreiro for preguiçoso, dê uma acelarada no andamento. A arquiteta pode exigir." Nessa carta, o conselheiro/articulista constrói a analogia a partir do universo discursivo da construção 
civil. Podemos entender que na avaliação por analogia o conselheiro/articulista se utiliza da forma velada para aconselhar o reclamante. Ao invés de "ir direto ao ponto", constrói seu enunciado-resposta por meio de analogias que, de certa forma, amenizam uma avaliação mais direta do problema e a proposição de uma resposta impositiva enquanto conselho.

Há, além da analogia, o movimento dialógico de avaliação por convergência. Esse movimento diz respeito à convergência entre a autoavaliação do reclamante quanto ao seu problema e a resposta apreciativa do conselheiro/articulista, ou seja, o conselheiro/articulista avalia o problema do reclamante de forma convergente ao modo como o reclamante já avalia seu próprio problema. Vejamos esse movimento nas cartas a seguir:

Ex.: 08 -Estou entrando em depressão! Meu namorado foi casado por muito tempo e a ex-mulher dele é linda, modelo, corpo perfeito. Eu sou bonita, mas normal. Estou até pensando em terminar, porque não consigo viver à sombra de tanta beleza. Como ele pode ter esquecido uma mulher tão maravilhosa quanto a ex? Me ajudem! Segundo o psiquiatra e colunista de NOVA Paulo Gaudencio, você sofre exatamente do mesmo problema que o tímido. Enquanto ele, toda vez que abre a boca, sonha ser profundo $e$ interessante, você talvez deseje ser uma combinação da atriz Angelina Jolie com a modelo Gisele Bündchen sempre que surge em público. Cobra de si mesma a perfeição total. Provavelmente aprendeu na infância que, para merecer o amor de alguém, precisava ser excepcional. O resultado é que vive em busca desse ideal. Quem coloca você para baixo é seu ego idealizado superexigente. Procure diminuir o alto nível de expectativa e aspiração, de censura e julgamento. E já parou para pensar no que significa ser atraente? Ser bonita é mais do que um conceito puramente estético. É ser também inteligente, competente. (CRN\#10)

Ex.: 09 -Pela internet, me relacionei com um cara que se descrevia como "moreno, alto, sarado" e que, num encontro cara a cara, era baixinho, franzino e... bem, nem me animei a investigar se o corpo era sarado. Não disse nada, mas fiquei furiosa. Se topar com outro mentiroso na web, posso desancar o cara? A internet propicia essas falcatruas, faz parte do jogo. Ele deve ter pensado que você reza pela cartilha do "mentiras sinceras me interessam" e que se surpreenderia ao descobrir que o baixinho franzino era um cara legal. Mas é uma frustração, reconheço. Só que não é caso de desancar ninguém é raro alguém se apresentar dizendo: "Eu ronco, tiro meleca do nariz, não abro a porta do carro, sou totalmente sem graça". Na hora de se autodescrever, o pessoal incrementa os dotes na maior cara-de-pau. $\mathrm{Na}$ próxima vez, saia de casa com uma boa reserva de humor e, se o sujeito for mesmo "moreno, alto e sarado", aleluia! (CRC\#03) 
Ex.: 10-Tenho 27 anos e estou casada há três com um homem de 30 que nunca me procura. Sou bonita, ando bem arrumada e tenho certeza de que sou desejável. Ele também é vaidoso, pratica jiu-jítsu e sei que não me trai. Nossos amigos acham que ele é gay. Como fazê-lo confiar em mim e me contar o que se passa? Aliás, o que se passa? Estranho mesmo. Vocês são casados há pouco tempo, era para a relação ainda estar dando um belo caldo. Mas vem cá... E quando namoravam? Era diferente? Ele era um übersexy com você ou já dava sinais de desinteresse? Bom, não há outra saída a não ser uma conversa franca. Dê a ele a certeza de que você o ouvirá deixando de lado sua porção "juíza" (que todas nós temos). Não o ameace, não o critique de antemão, apenas ouça. Se ele não destravar, sugira uma terapia. E, se nada disso funcionar, não se acomode, pense no seu futuro. Sexo não é algo desprezível numa relação, você sabe. (CRC\#02)

Na carta CRN\#10, a reclamante relata que está entrando em depressão por não se achar tão linda e atraente quanto à ex-mulher de seu atual namorado. Ela inclusive afirma que está pensando em terminar o relacionamento, pois "[...] não consegu[e] viver à sombra de tanta beleza." O conselheiro/articulista avalia o problema de forma convergente com o discurso da reclamante: "Você sofre exatamente do mesmo problema que o tímido [...]." Ao afirmar que a reclamante "sofre", ele a está avaliando de maneira convergente com a própria autoavaliação dela: "Estou entrando em depressão!"

Já na carta CRC\#03, a reclamante relata sua experiência em relacionar-se com "caras" pela internet. Ela relata estar frustrada por nunca encontrar homens que são fisicamente iguais ao modo como se descrevem na web. O conselheiro/articulista responde à reclamante ("A internet propicia essas falcatruas, faz parte do jogo.") de forma convergente a sua constatação [da reclamante]: "topar com mentirosos na internet." No exemplo da carta CRC\#02, a reclamante expõe que há três anos está casada com um homem que nunca a procura sexualmente: "Tenho 27 anos e estou casada há três com um homem de 30 que nunca me procura." O conselheiro/articulista, ao responder a carta, constrói seu discurso de forma convergente com a avaliação que a reclamante faz de seu problema, declarando: "Estranho mesmo."

Por outro lado, observamos que, além do movimento de avaliação por convergência, há na carta de conselhos um movimento dialógico de avaliação por divergência. Este se caracteriza como um movimento dialógico avaliativo a partir do qual $o$ conselheiro/articulista avalia o problema do reclamante de forma divergente do modo como o próprio reclamante se autoavalia.

Ex.: 11 -Tenho 34 anos e sonho em ter filhos, mas meu marido já tem três de outro relacionamento e não quer mais. Às vezes, penso em sabotar nosso método contraceptivo e dizer simplesmente que "falhou". Ele adora crianças e tenho certeza de que, depois, ficará tudo bem. É muito desleal da minha parte? Não faça isso. Filho não pode ser uma decisão solitária. A vida a dois é experiência de decisão partilhada! Tenho certeza de que você não fica feliz quando ele toma decisões importantes sem a sua opinião. Jogue limpo. É o melhor jeito de ganhar. (CRC\#04). 
Ex.: 12 -Namorei um rapaz dominado pela mãe. Chegamos a ponto de ela voltar tarde para casa só para ele tomar conta do irmão caçula e não sair comigo! Quando reclamei dela, ele terminou. Como lidar com alguém que não enxerga? Não queira se impor sobre o vínculo. Você vai perder. Freud já explicou tudo sobre isso.É o elo mais duradouro que trazemos na alma. É possível, porém, minimizar os poderes do vínculo, mas nunca batendo de frente. Seja ardilosa. Se com a mãe prevalece a prisão, ofereça um pouco de liberdade. Tenho certeza de que o prato que você lhe estenderá é bem mais saboroso. Mas não se engane: o trabalho será grande! (CRC\#07)

Ex.: 13 -Tenho um namorado maravilhoso, nosso relacionamento é excelente. Porém, ele me traiu. Confessou a traição, mas implorou para que eu continue com ele. Eu o amo muito, então resolvi dar uma chance, mas está sendo muito difícil aceitar tudo isso. O que vocês me dizem? Não é porque seu namorado não resistiu uma vez que está fadado a ser um eterno galinha. Para o psiquiatra e colunista de NOVA Paulo Gaudencio, ele pode voltar a ser fiel, desde que tenha uma motivação. "O instinto sexual precisa de novidade. Sendo assim, ser monógamo frustra uma necessidade natural. E aí, para eu aceitar uma frustração, preciso ter uma compensação. Seu namorado mudará de atitude ao ver vantagem em não passar mais pelo castigo de ser descoberto, em agradar a mulher amada, em investir em uma relação..." O dr. Gaudencio acrescenta que o que faz homens comprometidos traírem com tanta facilidade é a certeza da impunidade. Você decidiu dar a ele uma segunda chance. Disse ao rapaz que se vacilar novamente não terá seu perdão? Você ganha pontos se falar isso sem aquele tom agressivo, apenas com seriedade. No mais, é importante que o casal avalie a situação e tome essa decisão em conjunto. "Então, o que tem a fazer é superar a história e seguir em frente", aconselha a psicoterapeuta Alina Discepolo Barone. (CRN\#03)

$\mathrm{Na}$ carta CRC\#04, a reclamante expõe que sonha em ter filhos, mas que o marido, que já tem três de outro relacionamento, não deseja mais. Frente a essa situação, ela diz ter pensado em sabotar o método contraceptivo e dizer ao marido que simplesmente "falhou". O conselheiro/articulista, em um movimento avaliativo de divergência em relação ao discurso da reclamante, afirma: "Não faça isso." A avaliação divergente é marcada enunciativamente pela forma imperativa negativa: "não faça!".

$\mathrm{Na}$ carta CRC\#07, a reclamante relata que namorou um rapaz dominado pela mãe. Quando foi reclamar da sogra para o namorado, este resolveu terminar a relação. O conselheiro/articulista aconselha que a reclamante não se imponha sobre o vínculo materno, pois, segundo o conselheiro, ela irá perder. Com isso, ele responde de forma divergente em relação ao relato pessoal da reclamante.

Em relação à carta $\mathrm{CRN} \# 03$, a reclamante explica que tem um namorado excelente, porém que ele a traiu e confessou a traição. A reclamante resolveu dar uma chance ao namorado, mas expõe que está muito difícil aceitar a situação. O conselheiro/articulista inicia seu conselho afirmando: "não é porque seu namorado não resistiu uma vez que está fadado a ser um eterno galinha." Em outras palavras, o conselheiro/articulista 
antecipa, por assim dizer, a reação-resposta da reclamante em relação ao namorado e já responde de forma divergente, afirmando que o namorado não poder ser rotulado como um "eterno galinha".

$\mathrm{Na}$ análise dos movimentos dialógicos de avaliação do problema do reclamante, podemos entender como o conselheiro/articulista reage responsivamente aos testemunhos e relatos das vivências e experiências pessoais do reclamante, por meio de diferentes formas de avaliação. No movimento dialógico de avaliação por analogias, o conselheiro/articulista procura responder ao reclamante avaliando os problemas deste por meio de comparações verbo-apreciativas engendrados em universos discursivos diversos. Já no movimento dialógico de avaliação por convergência, o conselheiro/articula avalia os anseios íntimo-pessoais do reclamante de forma convergente à avaliação que este faz de seu próprio problema, a avaliação em encontro com a autoavaliação. Em contrapartida, no movimento dialógico de avaliação por divergência, o conselheiro/articulista avalia o problema do reclamante de forma divergente à avaliação que este faz do seu problema, a avaliação em desencontro com a autoavaliação.

De acordo com Bakhtin (2010[1986]), todo sujeito enuncia atitudes avaliativas sobre si e sobre o outro. Enquanto sujeito singular e único, ele sempre entra em relações valorativas com o mundo; estar e ser no mundo é posicionar-se valorativamente nopara-sobre o mundo. Sob essa perspectiva, o autor ainda esclarece que a ligação entre o conteúdo dos atos vivenciados e seu tom valorativo não são de ordem causal, mas entrelaçados na trama da história das experiências únicas desse sujeito. Com isso, podemos compreender que o tom emotivo-volitivo que o conselheiro/articulista enuncia em relação aos problemas expostos pelo reclamante não é ancorado estritamente no conteúdo da exposição (o testemunho íntimo-pessoal do reclamante), mas na sua correlação com a eventicidade do ato que o reclamante discursiviza em seu enunciado.

Em outras palavras, como a projeção de valor (avaliação) abarca e perpassa todo o existir-evento singular, o tom emotivo-volitivo do conselheiro/articulista constrói-se a partir dessa projeção das experiências únicas do sujeito em seu testemunho; constrói-se a partir do olhar exotópico do conselheiro/articulista para o ato volitivo-realizador do reclamante. Como esclarece Bakhtin (2010[1920/1924], p. 87), "viver uma experiência, pensar um pensamento, ou seja, não estar, de modo algum, indiferente a ele, significa antes afirmá-lo de uma maneira emotivo-volitiva."

Além disso, todos os índices sociais de valor são ideologicamente constituídos, isto é, mesmo que enunciados por sujeitos em seus atos singulares e únicos, constituem-se como projeções de valor com pretensões ao consenso social e "apenas em nome do consenso é que eles exteriorizam no material ideológico" (BAKHTIN (VOLOCHÍNOV), 2006[1929], p. 46). Todo enunciado é marcado pelo horizonte social de uma época e de um grupo social determinado. Os signos são, dessa forma, determinados pelas formas de interação verbal; seu conteúdo é determinado pelas condições sociais de interação e pelos índices sociais de valor, que, por sua vez, afetam todo o conteúdo. Compreendemos, a partir disso, que o conselheiro/articulista enuncia sua avaliação à luz de um determinado horizonte apreciativo (BAKHTIN, 2003[1979]; (VOLOCHINOV, 2006[1929]); BAKHTIN, 2008[1929]), ideologicamente constituído 
em relação ao reclamante. A valoração, portanto, juntamente com as demais instâncias da situação extraverbal, possibilitam a compreensão dos juízos de valor (das avaliações) que o conselheiro/articulista enuncia em relação aos problemas do reclamante.

Com isso, entendemos que o gênero carta de conselhos se insere na ininterrupta cadeia da comunicação discursiva, relacionando-se e confrontando-se com enunciados do outro. Um enunciado sempre responde a outro enunciado, seja a enunciados anteriores, os já-ditos, seja a enunciados pré-figurados, antecipando possíveis respostas (BAKHTIN, 1998[1975]). Em síntese, procuramos analisar como o conselheiro/articulista responde ao discurso do reclamante, como avalia esse discurso e como, na escrita de sua carta, evoca discursos já-ditos e antecipa discursos pré-figurados outros, construindo dialogicamente um acontecimento enunciativo marcado por embates, contradições e desencaixes. Assim, a análise acima nos mostrou que o gênero carta de conselhos se orienta por diferentes caminhos apreciativos e diferentes matizes semântico-ideológicos, ratificando a ideia de que "[...] é impossível entender o enunciado concreto sem que se esteja familiarizado com seus valores, sem que se entenda a orientação de suas apreciações.” (BAKHTIN, 1998[1975], p. 121).

\section{CONSIDERAÇÕES FINAIS}

Nesse estudo, analisamos o enquadramento de discursos outros no gênero carta de conselhos, procurando compreender a confluência dialógica entre já-ditos e préfigurados no discurso do conselheiro/articulista, além dos movimentos dialógicos de avaliação no encontro entre o discurso do reclamante a contrapalavra do conselheiroarticulista. Entendemos que este reenuncia o discurso já-dito de outrem e enuncia o discurso pré-figurado do reclamante com o intuito de validar seus pontos de vista e de antecipar possíveis respostas do reclamante sobre seus problemas íntimos. Dessa forma, os discursos já-ditos, assim como os pré-figurados funcionam como discursos de autoridade e de legitimação consubstanciando e, por conseguinte, reforçando a autoridade do discurso do conselheiro/articulista. Em relação aos movimentos avaliativos, estes consubstanciam a posição verbo-axiológica do conselheiro-articulista e, por conseguinte, orientam sua reação de resposta.

Em síntese, objetivamos neste estudo das relações dialógico-valorativas na carta de conselhos seguirmos o caminho metodológico de análise do gênero à luz dos escritos do Círculo, isto é, voltar nosso olhar para os gestos interpretativos balizados pelas feições do gênero à luz do encontro entre os dizeres, a alteridade e a valoração.

\section{REFERÊNCIAS}

AMORIM, M. O pesquisador e seu outro: Bakhtin nas ciências humanas. São Paulo: Musa Editora, 2004.

BAKHTIN, M. M.; VOLOSCHINOV, V. N. Discurso na Vida e Discurso na Arte (sobre a poética sociológica). Trad. De Carlos Alberto Faraco \& Cristóvão Tezza [para fins didáticos]. Versão da língua inglesa de I. R. Titunik a partir do original russo, 1926. 
- Marxismo e Filosofia da Linguagem: Problemas fundamentais do método sociológico na ciência da linguagem. Tradução do francês por Michel Lahud e Yara F.Vieira. $12^{\circ}$ ed. São Paulo: Hucitec, 2006 [1929].

BAKHTIN, M. M. Questões de Literatura e de Estética: a teoria do romance. Tradução do russo por Aurora Fornoni Bernardini et al. $4^{\mathrm{a}}$ ed. São Paulo: UNESP; Hucitec, 1998 [1975].

Estética da Criação Verbal. Tradução do russo por Paulo Bezerra. $4^{\mathrm{a}}$ ed. São Paulo: Martins Fontes, 2003 [1979].

. Problemas da Poética de Dostoiévski. Tradução do russo, notas e prefácio de Paulo Bezerra. 4a ed. Rio de Janeiro: Forense Universitária, 2008 [1929].

. Para uma filosofia do ato responsável. Tradução aos cuidados de Valdemir Miotello e Carlos Alberto Faraco. São Carlos: Pedro \& João, 2010 [1986].

BARROS, D. L. P. Dialogismo, polifonia e enunciação. In: ; FIORIN, José Luiz (Orgs). Dialogismo, polifonia, intertextualidade: em torno de Bakhtin. São Paulo: Edusp, 2001. p. 13-27.

BRAIT, B. Bakhtin: conceitos-chave. São Paulo: Contexto, 2006.

. O discurso sob o olhar de Bakhtin. In: GREGOLIN, M. R. do; BARONAS, R. (org.). Análise do discurso: as materialidades do sentido. São Paulo: Editora Claraluz, 2007, p. 19-32.

BRANDIST, C. Repensando o Círculo de Bakhtin. São Paulo: Contexto, 2012.

FARACO, C. A. Linguagem e diálogo: as ideias do Círculo de Bakhtin. São Paulo: Parábola, 2009.

- Linguagem \& Diálogo: as ideias linguísticas do Círculo de Bakhtin. Curitiba/PR: Criar Edições, 2006.

GERALDI, J. W. Portos de passagem. São Paulo: Martins Fontes, 2005. . Ancoragens - Estudos Bakhtinianos. São Carlos: Pedro e João Editores, 2010.

MORSON, G. S; EMERSON, C. Mikhail Bakhtin: criação de uma prosaística. Tradução de Antonio de Pádua Danesi. São Paulo: Edusp, 2008.

PONZIO, A. A revolução bakhtiniana. São Paulo: Contexto, 2009. . Procurando uma palavra outra. São Carlos: Pedro e João Editores, 2010.

RODRIGUES. R. H. A constituição e funcionamento do gênero jornalístico artigo: cronotopo e dialogismo. Tese (Doutorado em Linguística Aplicada e Estudos da Linguagem - LAEL - PUCSP). São Paulo: PUCSP, 2001.

Recebido em: 26/05/2013

Aceito em: 25/06/2013 